\title{
Programmer or Moderator: Redefining the Listener on Interactive Broadcasting
}

\section{Özgül Birsen, Anadolu University, Turkey}

\begin{abstract}
The subject of this study is new media and radio broadcasting performed with active participation of the listener as an example of citizen journalism. The radio programmer named "Nihat'la Muhabbet" (Conversation with Nihat) that is made by Nihat Sirdar, who is one of the radio hosts of the radio Alem FM broadcasting nationally in Turkey and who has a wide audience, is broadcasted every weekday between 7-9 a.m. During the program, the listener channels the program via twits on internet regarding the topic defined by the host. The primary aim of the study is putting forth which topics are considered in the program named "Nihat'la Muhabbet" (Conversation with Nihat) that is an example of the citizen journalism and in which the audience is actively participated. With this study, it is tried to put emphasis on appropriate structure of radio for citizen journalism with changing radio broadcasting in new media environment.
\end{abstract}

Keywords:Radio broadcasting, Citizen Journalism, Listener, New radio 


\section{Introduction}

During its adventure of almost a century, the radio has a technological change from large devices placed in the seat of honor in living rooms of homes to devices that can be listened from mobile phones. However, today it is possible to reach radio broadcasts not only by radio waves but also by GSM networks on internet. The content, quality, aim and functions of communication are inevitably changed by developments in media technology, especially spread of the large network internet throughout the world, the quickness of communication tools provided by digital technology, richness, multidimensionality, and multimedia technology. The most important advantage of radio compared to other mass media is that it appeals to imagination. The messages given via radio are envisaged on mind, and the voices on the listener's mind are transformed into messages. The effect and familiarity of pure human voice is an advantage for radio. In addition, the radio is very quick with its technical advantages since it doesn't require image and fiction. It is easy and simple for the listener and the broadcaster. It is enough to have ear to become a radio listener. The radio which does not require to be literate and which provides convenience to engage in other works while listening is a significant background in life of the listener. With the internet, the limits of the radio are removed and it becomes possible to listen any radio broadcast from all over the world. (Mcleish, 1994: 10-23).

The devices of new communication technologies are put on the market quickly and their models and brands are continuously developed. Technological change affects the old and new media especially in terms of content. Also the information and ideas spread by the communication tools varied from mobile phones to movable televisions, from bag-sized satellite phones to palmtop computers of which prices are decreasing day by day are inevitably affected by the process of change of communication tools (Duran, 1999:66). The radio is transported to the internet as e-radio since the internet started to appear in all stages of daily life. With the opportunities provided by the internet, it's now possible for everyone to broadcast their own program. Another important change for radio broadcasting is that the radio has become a media with screen. While the listener listens the radio on the internet, he/she is in interaction both with the host and other listeners. Facebook and twitter are the primary social network websites that are effective in this process. 


\section{Radio and Social Network Websites}

Each person is in interaction and relation with the others in community life. Family relations, friend relations, and labor relations make individuals become a part of different social networks. Social networks that are indispensable realities of community life take place in the new course with the development in internet technology. The websites like Facebook and Twitter fundamentally operate by imitating the social networks owned by individuals. Individuals are in relationship with their social networks without the internet. But the communication can be limited or lack as well as live and instant considering the geographical position of the individual in this relationship. Social network websites provides the communication of the individual with his/her social networks to become a constantly open channel, and provides the opportunity for the individual to reach the wide masses and establish relationship at the same time. The individual can become active in social network website in proportion to the broadness of the social network reflected on the internet.Today's audiences have a more active and participative role in media different from their traditional position through the social network websites. By this behavior called social watching, social listening or social reading, the audiences transfer the messages received from the media to the new course, the social media quickly; and they mediate for reproduction of the current content in the media in a different way. This new method in content reproduction is the reflection of the new role of audiences in the social network websites. Using methods of this content reproduction style can be in the format of increasing the effect of media content as well as of creating the media content by active participation of the audiences.

\section{Citizen Journalism}

Citizen Journalism aims to bring the ever-decreasing trust against media and journalists all over the world into safety and to reach the newspapers to much more readers in trust. Citizen journalism is also seen as an example of alternative publishing in new media environment such as peace journalism and rights journalism. The main purpose of citizen journalism is setting the citizen as news' transmitter and reporter by making the citizen the source of news. The news are brought up to the agenda by people who suffer from the issue directly with citizen journalism. Thus, news flow becomes not elite-based but citizen-based. This flow provides an equation in direction from the bottom to up, in other words from ones less represented to ones more represented (Alankuş, 2009: 88-125). 
The main characteristics of citizen journalism are as follows: The main purpose of citizen journalism is to produce news. Citizens are informed about daily problems. It allows people to realize their responsibilities in democracies as citizens. Citizen journalism aims to educate citizens against problems and daily events and encourage them to participate in decision processes related to them. The first objective of citizen journalism is to create awareness of ownership of the questions. The main objective is to ensure the active participation of citizens into the decision processes related to them. It is aimed for citizens to realize their rights and responsibilities. Citizen journalism aims for citizen to produce source and content of the news directly himself by broadening definition of news. The balance is aimed in news and it tries to remove the distance between newspapers and citizens for this purpose (Cangöz, 2003: 104).

It is aimed to reach all news sources in citizen journalism. Ordinary people cannot be news source when looked at regular news flow. Ordinary people are compressed into violence news. The poor and ordinary people are mostly described as heroes of the tragic stories rather than their daily problems. Citizen journalism will transfer the problems directly from the language of the victims that it will be transferring and presenting us the real problems. News is made by taking information from multiple sources. Information obtained from multiple sources is very important for reporter to approach the pure reality. (Duran, 2003).It is not a must for citizen journalism to obtain information from a reliable source. Reliable sources are usually authorized people who must solve the problems and complained by the ordinary citizens. The objective here is to criticize authorized people who are expected to be the subject of the news and to transform into people who are the sources of the problems (Özer, 2012:23-43).

An opponent and different voice is needed in today's media environment for private radio and television broadcasting that is criticized because of the reason that they are producing popular content which is often parroting each other. The cheap and easy nature of radio made it the voice of opposing thoughts for years. The broadcasting environment and legal limitations of Turkish radio broadcasting developed in government monopoly prevented the formation of opposing voices. However, radio has always been the voice of opponents by its nature. Technological developments lead the listeners to participate in radio programs actively in today's radio broadcasting. Citizen journalism may be an important evolution for private radio and television channels which are in search of alternative broadcasting. 


\section{Past and Present of Radio Broadcasting in Turkey}

Radio broadcasting is to be examined in five different periods in Turkey that are period covering the first private programs of Turkish radio broadcasting between the years of 1927 and 1964, period covering the PTT management between the years of 1937 and 1940, period covering the management under control of the Prime Ministry between the years of 1940 and 1946 and period after the TRT between the years of 1960 and 1980 and the last period which private radio broadcasting becomes free and all changes and developmentsoccurred in the last period star from the year of 1980 to today 2012. The radio broadcasting is established and operated on "January $6^{\text {th }}, 1927$ " by a private company as in cases of England, France and Germany. (Tekinalp, 2011: 95).

Radio broadcasting in Turkey that had begun in 1927 is carried to a different dimension in the late 1980s. The process of change accelerating in 1980s provided private radio and television broadcasting to be founded and spread in European countries. The changes, technological developments, political and cultural reasons in the world economy allowed the rapid development of radio and television broadcasting. In the late 1980s, various newspapers and entrepreneurs went into the effort of private radio and television broadcasting. A new trend was started in broadcasting by the 1990s. The process of establishment of private radio and television started to be experienced. First, private radio channels started to broadcast and then, discussions about legal arrangements took place. Some gave the name of "illegal broadcasting", some gave the name of "prohibited broadcasting" and some gave the name of "pirate broadcasting" to this period.

In this period, many institutions and private entrepreneurs broadcasted except the state-owned TRT broadcasting. Again during this period, police radios, the municipal radios and university radios participated in the broadcasting life. 1990s are the years that a media industry started to be formed. Commercial broadcastings are seen as samples of sprightliness, color and courage at first appearance in this period. But in time, radios and televisions broadcasting with commercial concerns became targets of criticism. Private radios and televisions have brought up a new broadcasting form to the agenda with their names, program contents and unusual presentations. The private radio and television channels are criticized of having a broadcasting understanding that they have only the purpose of entertaining, don't have any cultural and artistic value and contribute to the educational and cultural level of the 
society and change the popular culture products into mass culture products (Cankaya, 1997: 80-93).

\section{Method}

The program of "Nihat'la Muhabbet" which was broadcasted between 7-9 a.m. on weekdays between the dates of May $21^{\text {th }}$ and $26^{\text {th }}$ are randomly selected and recorded and these programs were classified according to their topics. The participation and content creation is provided by the topics set by the programmer, live telephone connections, SMS and twitter messages of the listeners. The topics determined at the beginning of the program is continued to be discussed during and after the program via messages. The topic set by the programmer is brought up to the agenda by discussion of the listeners. The print of subject of program dated May 21th among programs between May 21th to May 26th was taken and the program twits themed "bütçeye kaynak lazım" are evaluated in terms of citizen journalism. The examined criteria are as follows:

- Including citizens in decision-making.

- Accessing to all news sources.

- Reporting the citizen collected data as news by expanding the definition of news.

- Removing the distance between the newspaper and the citizen.

\section{Analysis}

Alem FM which is the subject of this study is ranking on third position coming after Kral FM and Super FM in the gradation of the most listening radios of Turkey according to the data of 2008/3 (July-August-September) period that includes KMG Ibsos radio listening habits. Alem FM that is one of the most popular radio stations defines itself as an entertainment and music radio. Alem FM diversifies its program content in a wide range from politics to arts, economy to sports, magazines, literature, animal rights and astrology. "Nihat'la Muhabbet" is broadcasted live on weekdays between 7 and 9 a.m. "Nihat'la Muhabbet" is examined in terms of listener participation and citizen journalism.

\section{Quantitative Results}

5-days programs in a total of 10 hours between the dates of May 21th to May25th are recorded and listened. The agenda topics selected by the programmer which hasn't brought up to the agenda in national news are read in a critical language and comments of listeners are 
received. The statements and actions of political leaders constitute the contents of issues brought up to the agenda often with a humorous language.

On the May $22^{\text {th }}$ Tuesday program, the programmer is determining the subject of the day as "Great Turkish Lies" after the newscast in the agenda. Sirdar ends the program by reading the incoming messages coming from the listeners about the subject.On the May $23^{\text {th }}$ Wednesday program, after reporting the detailed news on the agenda, messages and telephone connections about new source suggestions which may contribute to the state budget are made based upon Melih Gökçek's statement who is the Mayor of Ankara about the issue that occupants should pay fee for the cars that they park front of their houses.On May 24th Thursday program, the programmer reports the news on the agenda substantially. The "bütçeye kaynak lazım" themed messages continued to be shared.On the May 25th Friday program, the program starts with news on the agenda and the topic of part needs participation of listeners is determined as "who, what and why will we protest?"

The program dated May 21th begins with news of the weekend on the agenda because of the reason that it is the first day of the week. The titles of the agenda chosen by the programmer are as follows:

- Children poisoned from milk distributed by the state.

- Izmir clock towers robbery.

- Not placing wreath on the Ataturk statues on the day of Saturday, that is the Youth and Sports Day on May $19^{\text {th }}$.

- The issue of beating the 112 Emergency service doctors at Hakkari and mutual discussion of the Minister of Health with opposition about another subject.

- The issue that Istanbul Metropolitan Municipality spent 730 thousand liras for to announce that they will distribute 22 liras.

- Briberies in auctions of the Winter Universiade Erzurum held in 2011.

- Closure of Malatya Metallurgy at the request of U.S.A.

- The decision of the Forensic Medicine Institution about the sexually abused student in Siirt that his mental condition is not disrupted.

- The statement of the Minister of Labor and Social Security. 
- The issue of making the brother-in-law of Ali Babacan, the Deputy Prime Minister, the manager of a company with a salary of 28 thousand dollars.

The news which find little spaces in national newspapers are reported to listener by Nihat Sirdar with a cynical language. While he is reporting the news on the agenda, he benefits from his programmer experience and associates the news with the other news and the agenda and criticizes institutions and people regarding the government. In doing so, the content of the program is generated in an interactive way by the active participation of the listeners. After reporting the news on the agenda, the programmer wants the participation of the listeners. Then, the listeners send their experiences and opinions on this subject via SMS, GSM or twitter. He is calling for posts with the message "Do you have a brother-in-law like him?" based on the news about brother-in-law on the program dated May $21^{\text {th }}$. The other question of him is "What are the news which haven't been seen in national media but have drawn the attention of the listeners?". He again conveys the messages coming from listeners back to the listeners amusingly. The listener posts are continuing with May 19th celebrations and brotherin-law posts. The May 19th posts are an important problem that has occupied Turkey's agenda. The government had abolished the May 19th, Youth and Sports Day and this event lead the reactions of the Kemalist segment of the society and celebrations were organized and made in different regions of Turkey. Listeners are giving information about these celebrations. They are stating their reactions against the government while reporting these news. The programr reads the messages related to the news of "brother-in-law" which have humorous way while discussing the agenda together with the participation of the listeners. While listeners giving information about their brother-in-laws' salaries, they are underlining the gap between them and the government. The program ends with share of listeners' messages (posts) and telephone connections.

\section{The Samples of Citizen Journalism}

A total of 180 messages sent to the issue on the agenda which was determined by the programmer with the title of "bütçeye kaynak lazım" on the day of May 23th. The suggestion messages on this topic are as follows:The parking tax should be collected from the cars parked on the streets and sidewalks. (Five participants stated)

Tweet and internet tax should be collected. (Five participants stated) 
Birth tax, breathing tax, sex tax, volume (the area that you cover) tax should be collected.

(Eight participants stated)

Tax should be collected from people who sit in the bus. (Six participants stated)

They to use earthquake aids.(Seven participants stated)

Diamond tax may be increased from $1 \%$ to $18 \%$.(Three participants stated)

100 TL should be collected rather than 10 TL which is very low for a punishment when we lose our e-state password which we get for $1 \mathrm{TL}$ at first. (Four participants stated)

The officer difference must be added onto cell phone bill and the tax on it must be increased plus by $18 \%$ VAT (because of the reason that we already don't pay earthquake tax)

If there is a pricing per person who protest in Istiklal Square of Istanbul, there should not be external debt. (Three participants stated)

Protesting can be moneyed. Police should collect money rather than using tear gas on the protesters. (Three participants stated)

While buying pharmaceuticals from pharmacies, rather than getting 3 pharmaceuticals for 1 lira, they can be bought for 2 liras. (Three participants stated)

They can make the earthquake aids as source by creating an artificial earthquake. They made the double-ways similar with this method. (Four participants stated)

TR. ID. No tax should be collected from newborn babies. (Four participants stated)

The capital tax should be taken from residents of Ankara. (Two participants stated)

Tax should be collected from people who have less than 3 children. (Three participants stated)

Tax should be collected from poisoned children of the project of "School milk makes children brainbox." (Four participants stated)

The other issues noted by the other participants are as follows:

Tax should be collected from people who swear at politicians.

Tax should be collected from borborygmus of the poors.

The age of retirement should be 80 .

We heard that the welfare state will reach to the level of Canada when the state theaters are closed; then this source can feed us at least for 50 years. 
Laziness tax should be collected.

Fan tax should be collected according to sports teams.

They can take money from the Religious Affairs Administration because they seem to share a little bit big money to this institution.

We may transfer the $2 \mathrm{~B}$ lands into grooming system.

Deputies may pay their own telephone bills.

Recep Tayyip Erdoğan had nothing to specialize left that he can specialize himself now.

\section{Message Contents in Terms of Citizen Journalism}

Under this title, the messages about citizen journalism are evaluated based on these obtained data. It is seen that citizens bring the tax problem mostly to the agenda when the topics are sorted. The participants underline that it is collected tax almost from everything with a humorous language.

\section{Including the Citizens in the Decision-Making Process}

The most important criteria of the citizen journalism is to include the citizens in the decision making and discussion process. It is aimed to develop sensitivity to conserve the problems. The decisions regarding taxes that interest whole community are brought up to the agenda of the citizens. The citizens wittily share their ideas and suggestions about the subject with the programr and thus with the listener. Almost all of the sent messages are composed of important political decisions occupying the country's agenda. They are topics frequently occupying Turkey's agenda such as taxes collected on mobile phones, earthquake and drug taxes, frequently made protests, traffic and park problems, favoritism etc.

\section{Reaching All News Sources}

Citizen journalism is showing all aspects of an event as news source. People from various fractions contribute to the selected topic in line with their experiences and knowledge. The primary party of especially political topics is society. Thus the citizens in the street have a chance of transferring their opinions and knowledge; in other words the society, the primary party of the topic finds an opportunity to express them at first hand. In traditional media, politicians take place in producing news as parties, and government officials, the political elites take place as actors. Since feedback process is weak in such broadcasting, the society 
becomes a passive audience of news. On the other hand, when an interactive communication channel is opened, the society becomes not only consumer of news but also the content producer of it by means of discussion. This situation makes the society the source of new content.

\section{Making News the Information Received From the Citizens by Extending the Definition of News}

Any information received from the citizens is subject of citizen journalism. For the average man to take place in news in mainstream media, they must commit a crime or become a part of a tragedy. But in citizen journalism anyone can become the subject or a party of news. Citizens are the source and the follower of news. The program of Nihat Sirdar is formed by participation of the listener in the way determined by the programmer. The characteristic of the topic affects participation of the listener. When the selected topic requires knowledge and information, participants share not only their criticisms but also their knowledge. For example, during the discussion of the taxes, not only the charged taxes were criticized, but also many unnoticed details regarding taxes were shared by the participating listener. By this way, the tax topic was considered in an entertaining and informative way rather than being considered in a didactic and narrow framework.

\section{Remove the Gap between Broadcasting Institutions and Citizens}

Radio, television, and newspaper are traditional mass media that have a weak feedback. This weak feedback creates an insuperable gap between the audiences and the mass medium. The most important element in removing this gap has been the internet. This obstacle is started to be removed by e-mail and is completely removed through the spread of social network websites. Even though a programmer does not want to enter into an interactive communication process with his/her audiences, the discussion regarding the program and the programmer continue automatically. Nihat Sirdar, as the programmer, has formed his program's format with participation of the audiences by including them into the process. This approach increases the level of commitment of the listener to the broadcasting institution, to the program, and to Nihat Sirdar such that it's obvious the listener who actively participates in the program has participated before several times. 


\section{Conclusion}

In this study, the messages sent to the program named "Nihat'la Muhabbet" that is broadcasted on one of the most listened radios, Alem FM, in Turkey in mornings are examined in terms of citizen journalism. The primary aim of citizen journalism is make citizens included in decision-making processes concerning them, and to provide their democratic participation. Association with citizen journalism shows that it's a phenomenon about news. Thus there exists the expectation that the content produced by citizens must be in the format of news. However it does not necessary the topics that individuals in society want to know or learn, or that draw the attention of individuals are newsworthy. In other words, many topics out of the news perception created by mainstream media can be included in the domain of citizen journalism. Another important point is that news and content formats created by the mainstream media don't be necessarily used in the same way in citizen journalism. It's an inevitable result that courses appropriate for citizen journalism put forth their unique methods and styles; and go out of the frames shaped by mainstream media.

Citizen journalism is a format created upon the internet has provided the parties within the communication process accessible. They have been effective on forming the methods and styles of citizen journalism that high interaction and quick improvement and spread of social network websites. Citizen journalism can be performed by a traditional media institution as well as independently. In both cases, it is not possible to talk about a completely organized structure. In other words, there doesn't exist a process in which different dimensions of the subject are examined by different persons by making job definition on a topic, and then different parts are gathered and processed. There is an automatic development in citizen journalism. Participation is related to being willing.

The radio program named "Nihat'la Muhabbet" that is made by Nihat Sirdar on radio Alem FM every weekday morning is considered in terms of citizen journalism and examined in the study. The program is based on political humor and shaped by active participation of the listener. Sirdar starts his program by selecting a topic. The topic is shared with the listener on twitter before the program is broadcasted. It is also announced to the listener after the program is started. In this process, twitter is the course through which the topic is announced half an hour before the program, and the content is started to be determined before the program with participation of the follower. This provides the program to start in a high tempo 
even in the beginning. The content production is started at 7 a.m. for the program that starts at 7:30 a.m. It is also observed that the programmer is prepared for a failure in this process. During the program, the topic selected by Nihat Sirdar is shaped by active participation of the listener. Since the programmer is inclined to humor and the humor is given prominence, the selected topics are considered in this regard. As the selected topics are relevant to the political agenda, humorous approach is also considered in the same way. Politicians, political decisions, implementations are inveighed by the participants humorously. But the programmer tries to protect him and the broadcasting institution against the problems that can be occurred as a result of exceeding the legal limits. It is observed that the programmer frequently inform the listener about actions brought against him, and warnings and punishments received from Radio and Television High Council. Probably for this reason, all messages sent on twitter are not read on the program. Although it is not possible to observe during the research, the same is valid for short messages sent to the programmer.

It is understood from the received messages that the program is informative although the participants prefer a humorous style. The participants are tending to express their criticisms with certain examples regarding the topics against the society they think. Selected examples contribute to refreshing public memory as well as confront the listener with unknown or unrecognized facts. 


\section{References}

Cangöz, İncilay (2003). 'Yurttaş Gazeteciliği ve Yerel Basın' in Gazetecilik ve Habercilik, Derleyen Sevda Alankuş, İstanbul, IPS İletişim Vakfı Yayınları:101-118.

Özer, Ömer. (2012). 'Yurttaş Gazeteciliği: Eskişehir Örneğinde Bir araştırma', Alternatif Medya Alternatif Gazetecilik, Derleyen Ömer Özer, Literatürk Yayınları: 23-43.

Duran, Ragıp (2003). 'Yurttaş Gazeteciliği', içinde Gazetecilik ve Habercilik, Derleyen Sevda Alankuş, BİA IPS İletişim Vakfı Yayınları: 85-99.

Black, David, A. (2003). "Internet radio: a casestudy in mediumspecificity", Media, Culture\&Society.London: Sage Publications, 23.

Tekinalp, Şermin (2011).KarşılaştırmalıRadyoveTelevizyon, Beta Yayınları, 95.

Cankaya, Özden (1997). DündenBugüneRadyoTelevizyon, Beta Yayınları, 80-93.

McLeish, Robert (1994). RadioProduction. 3. Basım, Oxford: FocalPress, 10-23. 